\title{
MUSLIMS IN PIONEERING MODERN KNOWLEDGE: CHRONICLES OF THE FREELY OR UNCONSCIOUSLY SURRENDERED LEGACIES TO THE WEST
}

\author{
Abdulrahman Yusuf Maigida \\ Faculty of Education, University of Port Harcourt, Nigeria \\ yusuf.abdulrahman@uniport.edu.ng
}

Received: 30-09-2020

Revised: $10-10-2020$

Accepted: 03-11-2020

\begin{abstract}
The paper dwelt on exemplification of the role of early Muslim world in pioneering modern knowledge with a magnification of the legacies that these torchbearers in Islam bequeathed to the world. The peculiarity of Nigeria as a nation with more than half of its entire population as Muslims was retrospectively reviewed from the precolonial to colonial-era; focusing on scholasticism. The study was examined purely from the historical perspective, to appraise how the impressive efforts of the early Muslim pioneers of modern knowledge in Medicine, Chemistry, Physics, Astronomy, Geometry, Mathematics, History, Geography and Biological Sciences were undertaken. The study did not finish without the expression of concern on how the golden legacies of the early Muslim pioneers have been played down by the Muslims of today, where knowledge or groundbreaking discoveries are now credited to the West, making it look like stolen legacies or freely surrendered legacies to those who are currently worried about the development. Based on these genuine concerns, several wells thought out recommendations were penned down, not limited to a suggestion on growing above externally triggered wars and hostilities among Muslim nations, and giving peace and unity chance, to settle down to reflect on how sustainable progress can be achieved in the world of knowledge economy.
\end{abstract}

Keywords: Muslims, Pioneering Modern Knowledge, Chronicles, Freely and Unconsciously

Surrendered Legacies, The West.

\section{INTRODUCTION}

Literacy is all about a person's ability to read, write and calculate. Anyone who fails in this regard is termed an illiterate. However, it suggests that anyone who cannot read or write the Chinese Language is illiterate to the Chinese. The same thing goes for Arabic; anyone who can conveniently read and write Arabic, with proficiency in the use of Arabic figures is considered to be literate in Arabic. Because of this, any insinuation or conclusion that debases or relegates anything Arabic is a glaring error. To be literate, one must be educated in relation to the knowledge that shows that one is educated in those areas expected. It is therefore out of place to berate anyone who is literate in a particular aspect, because of his language mode which is not understood by the reigning authority. This is the situation in the history of education and colonialism in Nigeria. The north saw herself as an educated society, but not 
officially recognized by the colonialists. This stance of the north was part of the reasons why the northerners belatedly accepted formal western education, recognized by the colonialist.

In Nigeria, the attached loyalty to the religion of Islam among its adherents culminated in the early resistance to accepting western education, especially among the Muslim communities of the northern part of Nigeria. The south-western Muslims of Nigeria equally resisted western-styled education, but appreciated its inherent potential for development, even as avenue to properly propagate Islam. This acceptance was earlier manifested in the south than it was among the northern Muslims. In specific term, and to corroborate the reaction and disposition of the Muslim north, Kosemani \& Okorosaye-Orubite captures these initial reaction and nature of the people of northern Nigeria where ${ }^{1}$;

Western education under colonial rule would not and was not domesticated by Islam. Consequently, it faced opposition and was eclipsed by the prevailing Islamic orthodoxy in Nigeria particularly at the initial stage and still informs Muslim response to modern education in Nigeria today.

That the colonialists did not retain Arabic literacy in the north was due to the fact that they could not communicate in that sophisticated language. If European colonialists had not ignored Arabic literacy, the north would not have been perceived as backward literarily today, by the southerners ${ }^{2}$. It is on record that by 1914 when the merger of northern and southern protectorates became a reality and formal Western education was just beginning to be properly coordinated, Fafunwa accounted for about 25000 Quranic schools already existing in the north, where a total of 218,618 students were being taught various subjects through Arabic language ${ }^{3}$.

When considering what education is, there are three official systems of education in Nigeria. First, education that is traditional and indigenous to the people and communities where it is given is how Abdulrahman described traditional education system, in other words, it is known as African Traditional/Indigenous Education ${ }^{4}$. This is a system that predates all other systems of education in Nigeria and in many other climes too. Similarly, African Traditional/Indigenous Education remains a system that is as old as the emergence of all African traditional societies, because of the continuous transmission of values, norms, customs, and tradition of the societies, regarded as the people's culture; from one generation to the other. This cultural transmission across generations is the same experience in almost all African countries. There are two other systems of education which are prominent in most African countries, in particular, Nigeria. These are Islamic system of education and the formal western education (missionaries). These two systems of education in Nigeria are foreign and

${ }^{1}$ J. M Kosemani and A. K Okorosaye-Orubite, History of Nigerian Education: A Contemporary Analysis (Nigeria: Port Harcourt: University of Port Harcourt Press, 2002), 16.

2 Femi Abbas, 'Encounter with Richard Akinjide on Islam - The Nation Nigeria News', The Nation, Latest Nigeria News, Nigerian Newspapers, Politics (blog), 9 October 2020, https://thenationonlineng.net/encounter-withrichard-akinjide-on-islam/.

3 A. Babs Fafunwa, History of Education in Nigeria (London: Allen and Unwin, 1974), 101; Babak Amini, 'Agamenon R. E. Oliveira, \&lt;I\&gt;A History of the Work Concept: From Physics to Economics\&lt;/I\&gt; (New York and London: Springer, 2014)', Advances in Historical Studies 04, no. 04 (2015): 336-37, https://doi.org/10.4236/ahs.2015.44023.

${ }^{4}$ Y. M. Abdulrahman, Nigerian Educational History and Policy: The Beginning of the Past and Past of the Future, Revision (Nigeria: Port Harcourt: M \& J Grand Orbit Communications Ltd. ISBN, 2017). 
imported. Islam came from the Arabia, having a system regarded as Islamic system and Formal Western system came from Europe through the Christian Missionaries ${ }^{5}$.

Islam came to Nigeria through the desert at the upper hemisphere known today as northern Nigeria. Islam came with it, her educational system which became known at first in the country as Quranic education where traditional madrasabs were established all over places to educate Muslim children ${ }^{6}$. Soon, the Quranic education metamorphosed into Islamic education when it was no longer the learning of just the Holy Qur'an or Arabic, but because of the introduction of different aspects of religion and livelihood to become informed and practising Muslims ${ }^{7}$. The nomenclature's change from Quranic education to Islamic education was necessitated in the contemporary Nigeria, because of the knowledge expansion and scope of the education that was needed for an all round Muslim personality. Many aspects bothering on knowledge expansion started evolving even up to the advanced level of knowledge which Fafunwa and Jimoh highlighted to include: Al-Tafsir (commentaries on the Qur'an), Al-Ahadith (the traditions of the Holy Prophet (S.AW.) and commentaries thereon), Al-Fiqh (Jurisprudence), As-Sarf (grammatical inflexions), An-Nahw (syntax), Al-Mantiq (logic), Histab (arithmetic), Al-Aqa'id (Scholastic theology), Ilum ul-Usul (treatises on exegeses, and the principles and rules of the interpretation of the laws of Islam), Al-Jabr Wal'muqabalab (algebra) and $A l$ ma'nwa Wal'bayan (rhetoric and versification). It is clear that professionalization is now the characteristic of Islamic education and these disciplines are beyond what the education of Muslims would be limitedly known as Quranic education ${ }^{8}$.

Historically, it is important to mention here that Islam and Islamic learning or education predated Christianity and formal Western education in what is now called Nigeria since the $11^{\text {th }}$ Century, that is, more than three Centuries (300years). This period felt within the reign of Ume Jilmi the ruler of Kanem Bornu empire from 1085 to $1097^{9}$. Geographically, this empire was not just the Borno State of the contemporary Nigeria of today ${ }^{10}$, but extended to accommodate a sizeable part of the North-eastern Nigeria of Bauchi, Adamawa and Yobe States. Ifemesia in Abdulrahman ${ }^{11}$ even captures the international inclusiveness of Borno Empire, spreading to the Lake Chad and from far north to Fezzan. By estimation, Islam had existed in Nigeria for over 1000 years. 1000 years ago, when no one could have dreamt of a country to be called Nigeria; even the colonialists who caused the emergence of Nigeria as a

\footnotetext{
${ }^{5}$ Sara Humphreys et al., 'Becoming a Teacher: Experiences of Female Trainees in Initial Teacher Education in Nigeria', Teaching and Teacher Education 87 (1 January 2020): 102957, https://doi.org/10.1016/j.tate.2019.102957; Kamil Adeleke Adeyemi, 'The Trend of Arabic and Islamic Education in Nigeria: Progress and Prospects', Open Journal of Modern Linguistics 06, no. 03 (2016): 197-201, https://doi.org/10.4236/ojml.2016.63020.

${ }^{6}$ Abubakar Yakubu, A Comparative Overview of the Pondok and the Traditional Madrasab in Nigeria, 2018.

${ }^{7}$ Nasir Mohammed Baba, 'Islamic Schools, the Ulama, and the State in the Educational Development of Northern Nigeria', Bulletin de l'APAD, no. 33 (1 August 2011), https://doi.org/10.4000/apad.4092.

8 S. A Jimoh, Islamic Education in Nigeria: An Overview. In S. A. Jimoh (Ed.) Foundations of Education. (Ilorin: Niger: Indemac (Nigeria Publishers) Ltd., 2004); Fafunwa, History of Education in Nigeria, 4.

9 Abdulrahman Yusuf Maigida, 'Contemporary Islamic Education in Nigeria from the Rear View Mirror', American Journal of Educational Research 6, no. 4 (31 March 2018): 329-43, https://doi.org/10.12691/education-64-6; Fafunwa, History of Education in Nigeria.

${ }^{10}$ Israel Dunmade, 'Lifecycle Assessment Education in Nigeria: An Exploratory Evaluation of the Trend', Procedia Manufacturing 35 (1 January 2019): 447-52, https://doi.org/10.1016/j.promfg.2019.05.065.

11 Abdulrahman, Nigerian Educational History and Policy.
} 
country were, at that time, still wallowing in total ignorance as they foraged wildly and aimlessly in the darkness of life ${ }^{12}$.

The background, as given above is a confirmation that even in Nigeria, Muslims pioneered learning or education, though the type that the colonialists were also regarded to be illiterate to, because it was not in any way part of their educational orientation to have become Arabic literate. However, it was appreciated by the Europeans who had contact with the north early enough to meet the people very well educated, as they could read and write in Arabic. The potentials, in the erudition of the northerners can be credited to the unique efforts of scholars like Uthman Dan Fodio who started it all. Fodio's brother, Abdullah Fodio and Sultan Bello were recognized in the account of Abass as those who rose up and embarked on vigorous propagation of Islam which had enabled that divine religion to retain its vitality till today. In furtherance to the unique efforts of Uthman Dan Fodio and his son-Mohammad Bello, they were both recognised to have made such complex linguistic, theological, scientific and legal studies; evident in the numerous books numbering 93 and 97 respectively.

\section{PIONEERING SCHOLASTICISM IN NIGERIA}

As already indicated above, northern leaders pioneered knowledge and enlightenment in what is today known as Nigeria, particularly the north of Nigeria. The contact of the north with Islam brought with it Islamic learning and civilization. It should be noted that the coming of Islam into this country in the $11^{\text {th }}$ century presented the people with well structured and organized political/administrative system, judicial system, economic system, social system, as well as educational system in line with the dictates of the Qur'an and Sunnah. Scholasticism in northern Nigeria was even appreciated by a Scottish explorer and British naval officer, Bain Hugh Clapperton who visited Sultan Muhammad Bello and had a historic intellectual encounter with him in 1824. Clapperton eventually bowed to intellectual ability of the Sultan, after they were embroiled in a complex web of knowledge display ${ }^{13}$. There were series of questions, including those that bothered on theology which Sultan Bello asked him. Hugh Clapperton admitted and confessed he was not sufficiently versed in religious subtleties, to enable him resolve those knotty points.

Apart from that episode of 1824, Clapperton returned to Sokoto in 1826 and presented to Sultan Bello, a complete copy of Arabic Euclid, may be to prove a point or assert superiority of the whites; but Clapperton was surprised to see that the Sultan was already in possession of what he brought. Euclid is an ancient geometry book of 13 volumes originated and named after that Great Greek Mathematician-Euclid, which according to Taisak (2020) is renowned for his Graeco-Roman antiquity and best remembered for his treatise on geometry, i.e the Elements.

It is actually noticeable today, Muslim individuals and organizations are doing all they can to promote learning among Ummah (adherents of Islam), be it religious or secular. However, worthy of note is that Islam had had front-liners that were involved in pioneering modern knowledge and in a number of breakthroughs in various fields of human endeavours. These efforts have been documented, recognized and commended.

\footnotetext{
12 Abbas, 'Encounter with Richard Akinjide on Islam - The Nation Nigeria News'.

13 Abbas.
} 


\section{MUSLIMS IN PIONEERING MODERN KNOWLEDGE}

Undoubtedly, Islam has made noticeable contributions to modern education in the world. This has been possible because of the position of Islam on knowledge and education, which encourages learning, evident in both the Holy Qur'an and Hadith (Prophetic Traditions). With this, Islam in its adherents spurred Muslims to venture into the study of ancient people, generally in the fields of arts or humanities, science, technology, engineering and mathematics. Efforts of these Muslim pioneers were directed at various modern disciplines of Mathematics, Medicine, Astronomy, Physics, Chemistry, Zoology, Geography, Architecture, Philosophy and practically in all fields of human endeavors; still not excluding History, Arts and Literature/Poetry. Up till today, many branches of science are attributable to the pioneering efforts of the Muslims world. Corroborative of this is the submission of Mujtaba \& Lari, translated by Goulding who assert that 'nowadays, European and American historians and scholars all recognize and relate the fundamental contributions made by Islam to all modern advances in science, mathematics, technology, philosophy, in many way ${ }^{14}$.

Fafunwa wrote that it was Islam that revived the human pursuit of science and it was through the Arabs and not the Romans that the modern world achieved light and power through science'. Abass (2020) lends his voice to this assertion, when it comes to a discourse on how modern education evolved; Abass maintains that all science subjects that brought about technology and the modern civilization originated from Arabic language. For instance, subjects like Chemistry (Kaymiyau), Physics (Fisiyau), Algebra (Alibrau), mathematics (ArRiyadiyat) and several others in sciences were originally Arabic. Significantly too, record has it that it was the Muslim Arabs that invented figure (0) which paved way for the digital system in mathematics and made technology possible ${ }^{15}$.

A further justification from Fafunwa in Abdulrahman ${ }^{16}$ indicates that the compilation of great lexicons and development of philological learning in Islam, all were the efforts of Muslims in the 9th and 10th centuries. The Mohammed V University in Morocco today has a valuable collection of some of these early works. While alluding to the conclusion of Dauda who declares that:

...not only did Muslim Spain gather and preserve the intellectual content of the Ancient Greek
and Roman civilizations, it also interpreted and expanded upon that civilization and made a
vital contribution of its own in so many fields of human endeavours-in science, astronomy,
mathematics, algebra (itself an Arabic word), law, history, medicine, pharmacology, optics,
agriculture, architecture, theology, etc ${ }^{17}$.

Commitment and dispositions of the early Muslims in the exploration of knowledge and display of premium and values placed on learning and education is a clear manifestation exhibited in the earliest establishment of centres of higher learning. For at least a century before the Western world thought of establishing higher centres of learning, Fafunwa ${ }^{18}$ reveals

${ }^{14}$ Mujtaba Musavi Lari and Mujtabá Mūsavī Lārī, Western Civilisation Through Muslim Eyes (F. J. Goulding, 1977).

15 Fafunwa, History of Education in Nigeria.

16 Abdulrahman, Nigerian Educational History and Policy.

17 Aliyu Dauda, State Education in Northern Nigeria, 1st ed (Kano: Gidan Dabino, 2002).

${ }^{18}$ Fafunwa, History of Education in Nigeria, 42. 
that the Muslim world had established such institutions of higher learning in Basra, Kufa, Baghdad, Cairo and Cordova; which all began as religious schools located in mosques and later developed into universities.

One of these universities and first to be so established in the world was the University of Al-Karaouine in Morocco, by a lady named Fathima Al-Fibari who transformed the former mosque into a leading university in Natural Sciences in 859 . This is even a documented fact in the Guinness Book of World Records, as the world's oldest continuously operating degreegranting university. This university was acknowledged as educational and spiritual center of the Muslim world. Another Muslims established universities among the oldest and prominent all over the world are Al-Azhar and Nisamiyya Universities.

Al-Azhar University in Cairo, Egypt in 970 C.E is one of the oldest and continuous degree awarding institution. ${ }^{19}$ Also in this category of oldest Islamic Universities is the Nisammiya or Nizamiyya University in Iran, established by Khwaja Nizam al-Mulk in the 11th century, precisely in 1065 with its networks spreading across other Islamic world, such as Iraq, Iran, Afghanistan, Nishapur, Amul, Mosul, Heart, Damascus and Basra. In some accounts, they were regarded as the first well organized universities in the Islamic world, supported by the elite class and the royal establishment, they were even well-known in Europe. The most famous of Nizamiyya network was the one in Baghdad (Iraq), called Nizamiyya-al-Baghdad.

When appraising the overall situation about the involvement of Muslims in knowledge promotion, people should not be left in doubt, because the Holy Qur'an has compelled Muslim to be knowledgeable, male and female. From several other portions of the Qur'an, there are directives of Allah requesting man to observe nature, study natural phenomena, and see how God has created certain things in pairs; negative and positive, think about the alternation of days and nights as a result of the movement of the sun and the moon. This simply means that Allah wants us to philosophize and become scientific in our thoughts and actions, as symbols of erudition. It is therefore incumbent on every Muslim to seek knowledge, as the Qur'an emphasizes reading and writing as well as teaching (education) (Quran 96 v 1-5). Prophet Muhammad (SAW) admonishes a searching for knowledge, even if it means to the end of the world. ${ }^{20}$

This is no doubt the reason why the Muslims have swung into action making their impacts felt in various spheres of human endeavours. Considering the fundamental contributions of Islam, several authors had written, among whom Wilds \& Lettich in Kosemani \& Okorosaye- and from the Encarta ${ }^{21}$, reviewing the contributions of the Muslims, Dauda, quoting Prince Charles of Wales in 1993 who lamented that:

We have under-estimated the importance of 800years of Islamic society and culture in Spain, between $8^{\text {th }}$ and $15^{\text {th }}$ centuries. The contributions of Muslim Spain to the preservation of classical learning during the dark ages (of European History!) and to the first flowering of renaissance has long been recognized....22

${ }^{19}$ John Renard, 101 Questions and Answers on Islam. (New York: Paulist Press, 2005), 1-5.

20 Thakur in Kosemani and Okorosaye-Orubite, History of Nigerian Education: A Contemporary Analysis, 11.

21 'Microsoft Releases Microsoft Student with Encarta Premium 2008', Stories, 26 June 2007, https:// news.microsoft.com/2007/06/26/microsoft-releases-microsoft-student-with-encarta-premium-2008/.

${ }^{22}$ Dauda, State Education in Northern Nigeria, 12. 
More importantly, the Prince of Wales asserts that "many of the traits on which the modern Europe prides itself today, came to it from Muslim Spain". Charles concluded that "Islam is part of our past and present in all fields of human endeavours; it has belped to create modern Europe".

\section{MUSLIMS PIONEERS IN THE FIELDS OF MODERN KNOWLEDGE}

As earlier maintained, almost all the modern disciplines were developed and promoted by the early Muslims, thus:

\section{Astronomy and its Sub-Disciplines}

The field of Astronomy was also reported by Fafunwa to be dominated by the Muslims who built several observatories and constructed many types of astronomical instruments which are used in modern education till today. The Muslim scholars were those who worked out the angle of the elliptic as well as the precession of the equinoxes ${ }^{23}$.

The scientific study of Astronomy in Islam started under the influence of an Indian production which was translated into Arabic by Mubammed bin Ibrabim Al-Fazari. In connection with the Baitul Al-Hikmah Al-Maamun erected at Baghdad near Shamasiyah gate an astronomical observatory under the directorship of Sa'id Ibn Ali and Yahaya bin AbiMansur who were the Caliphs. Astronomers did not only make the systematic observation of celestial movement, but also verified with precise result on the fundamental elements of Almagest. The obliquity of the elliptic, the precession of equinoxes, the length of solar year and so on, are constituents of Almagest.

Ibrabim Al-Fazari was the first Muslim to construct an Astrolabe. One of the earliest Arab works on this instrument was written by Ali bin Isa popularly known as Al-Asturlabi. Another eminent astronomer of the period was Abu Abass Ahmad Al-Farghani. Al Farghani's principal work was entitled Al-Mudakbir Ila Ilmi Hayat Al-Falak (Evocative introduction to the science of astronomy). Between 877 and 918, Al-Farghani made his observations and he studied in the town of Raqqah.

Al-Farghani was one of the greatest astronomers in Islam. He was an original research worker who made several amendments to the works of astronomers before him; including the rectification of the calculation for orbit of the moon (going round) and certain planets. Not only that, he proved the possibility of the eclipses of the moon and determine with greater accuracy the obliquity of elliptic and presented the original theories on the determination of the new moon.

A distinguished Professor of History and Philosophy of Science in Indiana University reported that Abu Ali al-Hasan ibn al-Haytham (Alhazen) in astronomy, to have added to the theories of the 2nd-century astronomer Ptolemy. He also summarized or explained some of the difficult mathematical theorems of the ancient Greek mathematician Euclid. The likes of Al-Batani and $A b d u l W$ afa were also notable Astronomers.

Apart from being a mathematician, Abul Wafa also made unforgettable contributions to astronomy. In this field, he discussed different movements of the moon, and discovered 'variation'. As mentioned by Moussa, Abu Al-Wafa' was the first to build a wall quadrant to observe the sky. It has been suggested that he was influenced by the works of Al-Battani as the

\footnotetext{
${ }^{23}$ Fafunwa, History of Education in Nigeria, 23.
} 
latter describes a quadrant instrument in his Kitāb $a z_{-} Z i^{24}$. His use of tangent helped to solve problems involving right-angled spherical triangles, and developed a new technique to calculate sine tables, allowing him to construct more accurate tables than his predecessors ${ }^{25}$. Among his works on astronomy, only the first seven treatises of his Almagest (Kitäb al-Majisțî) are now extant $\mathrm{t}^{26}$. The work covers numerous topics in the fields of plane and spherical trigonometry, planetary theory, and solutions to determine the direction of Qibla ${ }^{27}$. The contribution of Abul Wafa is incomplete, if this study fails to recognize him as one of the last Arabic translators and commentators of Greek works.

\section{Field of Geometry}

Specifically in Geometry too, the Muslims (Arabs) made great advances and developed spherical trigonometry which Wells particularly mentioned to include the sine, tangent+cosine and cotangent $^{28}$. Al Battani (877-918) was prominent in geometry and trigonometry ${ }^{29}$ (Galandaci, 2003:4) ${ }^{30}$. Al-Battani is sometimes known by a Latinised version of his name, variants being Albategnius, Albategni or Albatenius. His full name was Abu Abdallah Mohammad ibn Jabir ibn Sinan al-Raqqi al-Harrani al-Sabi al-Battani. Following his sterling contribution to the knowledge of geometry, the account of O'Connor \& Robertson rated Al-Battani as ${ }^{31}$ :

one of the famous observers and a leader in geometry, theoretical and practical astronomy, and astrology. He composed a work on astronomy, with tables, containing his own observations of the sun and moon and a more accurate description of their motions than that given in Ptolemy's

"Almagest". In it moreover, he gives the motions of the five planets, with the improved observations he succeeded in making, as well as other necessary astronomical calculations. Some of his observations mentioned in his book of tables were made in the year 880 and later on in the year 900 . Nobody is known in Islam who reached similar perfection in observing the stars and scrutinizing their motions. Apart from this, he took great interest in astrology, which led him to write on this subject too: of his compositions in this field I mention his commentary on Ptolemy's.

24 Ali Moussa, 'Mathematical Methods in Abū Al-Wafā's Almagest and the Qibla Determinations', Arabic Sciences and Philosophy 21, no. 1 (March 2011): 1-56, https://doi.org/10.1017/S095742391000007X.

${ }^{25}$ Ronald Florence et al., 'Būzjānī: Abū Al-Wafā' Muhammad Ibn Muhammad Ibn Yaḥyā Al-Būzjānī', in The Biographical Encyclopedia of Astronomers, ed. Thomas Hockey et al. (New York, NY: Springer New York, 2007), 188-89, https://doi.org/10.1007/978-0-387-30400-7_223; Thomas A. Hockey, Virginia Trimble, and Katherine Bracher, eds., The Biographical Encyclopedia of Astronomers, Springer Reference (New York: Springer, 2007).

${ }_{26}$ David A. King, 'E. S. Kennedy: Survey of Islamic Astronomical Tables 1956', accessed 5 November 2020, https://www.academia.edu/38529832/E_S_Kennedy_Survey_of_Islamic_Astronomical_Tables_1956; Kiki Kennedy-Day, Books of definition in Islamic philosophy: the limits of words (London; New York: RoutledgeCurzon, 2003).

${ }^{27}$ Moussa, 'Mathematical Methods in Abū Al-Wafā's Almagest and the Qibla Determinations'; Florence et al., 'Būzjānī'.

${ }^{28}$ H. G. (Herbert George) Wells and J. F. (James Francis) Horrabin, The Outline of History: Being a Plain History of Life and Mankind, ed. Ernest Barker et al., 2014, http://www.gutenberg.org/ebooks/45368.

${ }_{29}$ B. S Galandaci, 'Islamisation of Knowledge Undertaking and the Contemporary Nigerian Educational System.' (National Conference of Nigerian Association of Model Islamic Schools (NAMIS), 2003).

30 Sarfaroz Niyozov and Nadeem Memon, 'Islamic Education and Islamization: Evolution of Themes, Continuities and New Directions', Journal of Muslim Minority Affairs 31, no. 1 (1 March 2011): 5-30, https://doi.org/10.1080/13602004.2011.556886.

${ }^{31}$ Florence et al., 'Būzjānì'. 
Al-Battani's book-Kitab al-Zij has 57 chapters and this is by far his most important work $^{32}$. It begins with a description of the division of the celestial sphere into the signs of the zodiac and into degrees. The necessary background mathematical tools are then introduced such as the arithmetical operations on sexagesimal fractions and the trigonometric functions. Chapter 4 contains data from al-Battani's own observations. Chapters 5 to 26 discuss a large number of different astronomical problems following to some extent material from the Almagest. The motions of the sun, moon and five planets are discussed in chapters 27 to 31, where the theory given is that of Ptolemy but for al-Battani the theory appears less important than the practical aspects.

\section{Mathematics Discipline}

In the field of Mathematics, the name Mubammad Ibn Musa Al-Khwärizmi is notable. Because of his outstanding contribution to the field of Mathematics and great scientific prowess, he was nick-named Al-Khwarizmì - the name of his town with which he was frequently called and addressed.

Apart from his compilation of the oldest Arithmetic, Al-Khwarizmi also composed the oldest work on Algebra, last of such was called Hisabul Jabr Wal-Maqabala, meaning - the calculation of integration and equation, translated into Latin in the 12th century so that people who were not Arabic literate could benefit. Basically, he was the first to use for mathematical purposes in the expression al-Jabr, from which the English word algebra is derived. ${ }^{33}$

Arabic numerals called Algorithm were also introduced to Europeans by Al-Khwärizmi. According to Hittin in Abdulrahman, Algorithm is a corrupted form of Al-Khwarizmi. Ibn Musa according to Fafunwa ${ }^{34}$ was the first to use decimal notation and give digits the value of position. Other celebrated Muslim mathematicians influenced by Al-Khwärizmi’s works include Thabit Ibn Qurra (b. A.D. 826), Mubammad Ibn Ahmad and Umar al-Khayyan ${ }^{35}$.

Another great mathematician of repute, revered in the history of Islam and pursuit of scholasticism was Abul Wafa Muhammad Ibn Mubammad Ibn Yabya Ibn Ismail al-Busjani. He was born in Buzjan, Nishapur in 940 C.E. Apart from being a mathematician, Abul Wafa al Buzjani also flourished in his time as an astronomer. His first place of studies was Baghdad, after which he migrated to Iraq in 959 C.E $\mathrm{E}^{36}$. and spent his entire life there till death. His contributions to modern knowledge span several branches of mathematics, especially in geometry and trigonometry. For his contribution in geometry, al Buzjani proffered solution to geometrical problems with opening of the compass, construction of a square equivalent to other squares, regular polyhedral, construction of regular hectagon, taking for its side half the side of the equilateral triangle inscribed in the same circle; constructions of parabola by points and geometrical solution of the equations:

$\mathrm{x}^{4}=\mathrm{a}$ and $\mathrm{x}^{4}+a \mathrm{x}^{3}=\mathrm{b}$ 2011).

32 Mohammad Abdullatif, 'Al-Battani Contributions in Astronomy and Mathematics' (Malaysia: IIUM Press,

33 'Microsoft Releases Microsoft Student with Encarta Premium 2008'.

${ }^{34}$ Fafunwa, History of Education in Nigeria, 43.

35 Abdulrahman Yusuf Maigida, 'The Contributions of Islamic Organisations to Modern Education Development in Nigeria 1922-2008' (Nigeria, Thesis in the Department of Educational Foundations, University of Port Harcourt., 2010).

36 TMO, 'Muslim Scientists and Thinkers-Abul Wafa Ibn Ismail al Buzjani', The Muslim Observer (blog), 26 November 2008, http://muslimobserver.com/muslim-scientists-and-thinkers-abul-wafa-ibn-ismail-al-buzjani/. 
In the development of trigonometry, Abul Wafa's contribution was extensive and superlative, as he was the first to show the generality of the sine theorem relative to spherical triangles or simply put that he discovered the law of sines for spherical triangles thus:

where $A, B, C$ are the sides (measured in radians on the unit sphere) and $a, b, c$ are the opposing angles.

However, some sources according to Jacques suggest that he introduced the tangent function, although other sources give the credit for this innovation to al-Marwazi. Similarly, Abul Wafa developed a new method of constructing sine tables, the value of sin 30' being correct to the eighth decimal place. He also developed relations for sine $(a+b)$ and the formula, thus ${ }^{37}$ :

$2 \sin ^{2}(a / 2)=1-\cos a$, and

$\sin \mathrm{a}=2 \sin (\mathrm{a} / 2) \cos (\mathrm{a} / 2)$

According to O'Connor \& Robertson ${ }^{38}$, he was adjudged the first to compile and calculate the tables of sines and tangent at $15^{\prime}$ - intervals, as shown in a special study he carried out. It has not ended,in the efforts of Abul Wafa; as he introduced the secant and cosecant for the first time, knew the relations between the trigonometric lines, which are now used to define them, and undertook extensive studies on conics. Also, his work on arithmetics for businessmen contains the first instance of using negative numbers in a medieval Islamic text.

He wrote a large number of books on mathematics and other subjects, most of which have been lost or existing in modified forms. In the list of Abul Wafa al-Buzjani are: Kitab 'Ilm al-Hisab (a practical book of arithmetic), al-Kitab al-Kamil (the Complete Book), Kitab al-Handsa (Applied Geometry). Apart from this, he wrote rich commentaries on Euclid, Diophantos and al-Khawarizmi, but all of these have been lost. His books now extant include Kitab 'Ilm al-Hisab, Kitab al- Handsa and Kitab al-Kamil.

\section{Physics Discipline}

Equally in Physics, the Muslim Arabs invented the pendulum and advanced the world's knowledge of optics; famous on this was Hasan Haytham (Oladosu, 2005:6). Hasan Ibn al-Haytham, known as Alhazen by Latin modification, but originally $A b \bar{u}$ 'Ali al-Hasan ibn al-Hasan ibn al-Haytham 965 -1040) was an Arab mathematician, astronomer and physicist of the Islamic Golden Age ${ }^{39}$. Al-Haytham is popularly referred to as "the father of modern

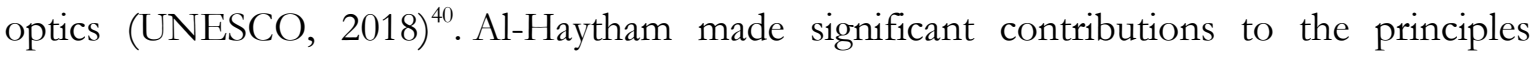
of optics and visual perception in particular. His most influential work is titled Kitäb al-Manāąir (Book of Optics), written during 1011-1021, which survived in a Latin edition. He is one of the principal Arab mathematicians and, without any doubt, the best physicist.

37 Helaine Selin, ed., Mathematics Across Cultures: The History of Non-Western Mathematics, Science Across Cultures: The History of Non-Western Science (Springer Netherlands, 2000), https://doi.org/10.1007/978-94011-4301-1.

38 J J O’Connor and E F Robertson, 'Al-Battani - Biography', Maths History, 1999, https:/ / mathshistory.standrews.ac.uk/Biographies/Al-Battani/.

${ }^{39}$ John L. Esposito, The Oxford History of Islam (Oxford University Press, 2000).

${ }^{40}$ W. P Heinrichs et al., The Encyclopaedia of Islam, 1960. 
Ibn al-Haytham was the first to explain that vision occurs when light reflects from an object and then passes to one's eyes ${ }^{41}$. He was also the first to demonstrate that vision occurs in the brain, rather than in the eyes. Building upon a naturalistic, empirical method pioneered by Aristotle in ancient Greece, Ibn al-Haytham was an early proponent of the concept that a hypothesis must be supported by experiments based on confirmable procedures or mathematical evidencean early pioneer in the scientific method five centuries before Renaissance scientists.

\section{Chemical Science}

In Chemistry, Muslims (Arabs) are again known to have made valuable contributions in Chemistry. The field of chemistry was characterized with many discoveries by the MuslimArabs, the discovery of substances like potash, silver nitrate, corrosive sublimate, and nitric and sulphuric acids. An important name in the field of Chemical Science was Abu Musa Jabir Ibn Hayyan, popularly called Geber by Europeans. History has it that Khalid Ibn Yazid Ibn Muawiyyah and Jafar As-Sadiq (the 6th Shiite Imam) were his teachers. Jabir believed that some base metals like iron or tin, lead or copper could be converted to gold using mysterious substances. Encarta asserts that more than 500 treatises have been ascribed to him. Contemporary scholars, however, believe that most of these works date from the 9th to the 12 th century ${ }^{42}$.

Among Jabir's discoveries was the scientific description of the two (2) principal operations of Chemistry (oxidation and reduction). Also, he made an improvement on the method of evaporation, sublimation, melting and crystalisation. Generally, Jabir also modified the Aristotelian Theory of the Constituents of Metal in a way that survived with slight moderation until the beginning of modern Chemistry in $18^{\text {th }}$ century.

\section{Medical Sciences}

In Medicine, Muslims advanced the frontiers of knowledge. The study of physiology and hygiene and their materia medica is still in use till today; so are many of Muslims' methods of treatment. Wells noted that at the time when in Europe the practice of medicine was forbidden by the church, which expected cures to be effected by religious rites performed by the clergy, the Arabs had a real science of medicine. In supporting this, Prince Charles of Wales in 1993 unequivocally submitted that the Muslim Spain was then a centre of pilgrimage for European aristocrats and their bourgeoisie and particularly for medical check-ups and treatment ${ }^{43}$.

Important among the earliest Muslim pioneers in medicine was Shaykh Abu Bakr Zakariyah al-Razi (Latin: Rhazes). He was probably the most original of all Muslim Medical Scientists. According to Grant, Al-Razi's medical writings greatly influenced the Islamic world as well as Western Europe in the middle Ages. Al-Razi whose full name is Abu Bakr Mubammed Ibn Zakariyah al-Razi was born and also died in Shahr-e Rey, Iran; near Tehrān $(\text { Teheran })^{44}$.

${ }^{41}$ Peter Adamson and Peter Adamson, Philosophy in the Islamic World, A History of Philosophy without Any Gaps, volume 3 (United Kingdom: Oxford University Press, 2018).

42 'Microsoft Releases Microsoft Student with Encarta Premium 2008'.

43 Wells and Horrabin, The Outline of History, 17.

${ }_{44}$ Ayman Shihadeh, The Teleological Ethics of Fakhr Al-Din al-Razi, vol. 64 (Рипол Кмассик, 2006); Franz Rosenthal, 'Ar-Razi on the Hidden Illness', Bulletin of the History of Medicine 52, no. 1 (1978): 45-60. 
Al-Razi wrote on almost every aspect of medicine. He published well over a hundred books, including al-Hawi (The Comprehensive Book, or Liber continens) an Encyclopaedia of Medical Knowledge which was later translated into Latin and remained a standard work in medical schools for 700 years ${ }^{45}$. In his most famous work, Treatise on Smallpox and Measles; Razi is best remembered as the pioneer of the earliest known description of smallpox.

Another renowned Islamic scholar in the area of Medicine was Abu Ali al-Husayn Ibn Abdallah Ibn Sina (Avicenna)-980-1037. Ibn Sina was an Iranian Islamic philosopher and physician. Regarded by Muslims as one of the greatest Islamic philosophers and whom Fafunwa ${ }^{46}$ describes as a prince of physicians, Avicenna is an important figure in the fields of medicine and philosophy. Just like Al-Razi ${ }^{47}$, he had so many books to his credit, precisely 99 books. Famous among these books was the (Qanun) The Canon of Medicine which Encarta remarks, was long preeminent in the Middle East and in Europe as a textbook.

Avicenna's best-known philosophical work is Kitab ash-Shifa (Book of Healing), a collection of treatises on Aristotelian logic, metaphysics, psychology, the natural sciences, and other subjects. Other Muslim medical scientists include Abu'l-Qais and Ibn Zahr, both of Andalusia; Abbas of Iran, Ali Ibn Rezvan of Egypt, Ibn Butlan, Masooya and Ali Ibn Esau all of Baghdad; Abu Mansur Muwaffaq of Heart, Ibn Wafeed of Spain and Ammar of Monsul.

Ibn Rushd of Cordova known as Averroes in the western world is $A b u$ al-Walid Muhammad ibn Abmad ibn Mubammad (ibn Rushd) who lived 1126 - 1198. Ibn Rushd stands out as the culminating influence of Arab's philosophy upon European thought (Wells, 1972:126). His father, a judge in Córdova, instructed him in Muslim jurisprudence. In his native city, he also studied theology, philosophy, and mathematics under the Arab philosopher Ibn Tufayl and medicine under the Arab physician Avenzoor ${ }^{48}$. In medicine, Ibn Rushd's works were translated to Latin and used in European Universities ${ }^{49}$. It was further remarked that Europe knew nothing of Cholera bacterium when Islam entered Spain and the people there regarded the disease as a punishment sent from heaven to exert the penalty of sins. Averroës's main independent work was Tahafut al-Tahafut (Incoherence of the Incoherence), a rebuttal of the attack on Neoplatonic and Aristotelian philosophy by the Islamic theologian al-Ghazali ${ }^{50}$. Averroës also wrote books on medicine, astronomy, law and grammar ${ }^{51}$.

${ }^{45}$ M Dawud, 'Towards Establishing Islamic Schools and the Challenges before Muslim Proprietors and Proprietress' (the National Conference of Nigerian Association of Model Islamic Schools (NAMIS) in Ibadan., Nigeria, 2003).

46 Fafunwa, History of Education in Nigeria, 43.

${ }^{47}$ Houchang D. Modanlou, 'A Tribute to Zakariya Razi (865-925 AD), an Iranian Pioneer Scholar', 2008.

${ }^{48}$ N. N. Glatzer, Averroes (Encarta, 2008). 1990).

49 Ibnu Rusyd, Bidayatul Mujtabid Wa Nihayah Al-Muqtashid (Lebanon: Beirut: Dar al Kutub al 'Ilmiyah,

${ }^{50}$ Jean-Baptiste Brenet, 'Relation as Key to God's Knowledge of Particulars in the Tahāfut Al-Tahāfut and the Damīma: A Cross-Talk Between Averroes, Al-Gazālī and Avicenna', Arabic Sciences and Philosophy 30, no. 1 (March 2020): 1-26, https://doi.org/10.1017/S0957423919000109; Danilo Garcia, Trevor Archer, and AnnChristine Andersson Arntén, Character, Responsibility, and Well-Being: Influences on Mental Health and Constructive Behavior Patterns, 2016.

51 Sayid Mujtaba and Rukni Musawi Lari, Western Civilisation Through Muslim Eyes (Sadr Publishing House, 1977). 


\section{Biological Sciences (Zoology)}

In the fields of Zoological and Biological Sciences, Islam had also made its mark. A man known as Amr bin Bahr popularly called Al-Jahizi (goggled eyes), because of his protrudent eyes wrote a book called Kitabul Al-Hayawanah (a book of animals), though the book was more of theology and a folklore than Biology. However, the book with its title is not a misrepresentation because; it dealt with the evolution of animals and the psychology of beasts. Al-Jahiz knew in the Arab world how to obtain a substance called ammonia from animal's offal by dry distillation. Later, Zoologists such as Al-Qazwini and Al-Damiri benefitted from its book. Al-Damiri is considered the greatest of Arabs' Zoologists. He was an Egyptian, while Al-Qazmini was a Persian. Other scholars in Europe came in contact with the work of Al-Jahiz and derived a lot of benefits from it. The dexterity of Ibn Haytham made him a zoologist, because of his pragmatic disposition that got him fascinated to experimentation in his studies, Ibn al-Haytham as noted in Baker ${ }^{52}$ was among the first scholars to experiment with animal psychology ${ }^{53}$.

\section{Geography and Adventure}

On Geography, Yaqub bin Ishaq Al-Kindir and Abu al-Hassan Ali Mas'udi were distinguished. For a proper understanding of astrology, a good knowledge of Geography is essential because Geography explains the latitude and longitude of all places throughout the world. The earliest Muslim traders in the 7th and 9th century reached China in the Far East, got to Zanzibar (an island of present day Tanzania), reached Russia to the North and the Atlantic Ocean, known as the Sea of Darkness.

In view of the above, reports of such merchants provided the first Arab's description of China and lands along the coasts of India. One of these traders, Sulayman reported that Chinese used fingerprints as signatures. Another one called Ahmad bin Fadlan came to report that they found a lot of things in Russia, all these stories and more helped another Arab called Yaqub when compiling his monumental dictionary called Mu'jam Al-Buldan. Basically, AlKindir studied Greek science and composed 265 treatises on Music, astronomy and Medicine. $^{54}$

What probably aided the study of Geography by the Arabs was a translation of Greek write-up into Arabic. This Greek write up was 'Ptolemy' while the Arab who translated it was Yaqub bin Ishaq Al-Kindir. Khwarizmi the Mathematician also benefitted from this work after it has been translated because it helped him to compose a book in which there was a map, the book was titled Suratul Ard (Picture of the Earth) ${ }^{55}$. The book stimulated many more Arabs to do Geographical studies ${ }^{56}$.

52 David B. Baker, ed., The Oxford Handbook of the History of Psychology: Global Perspectives, Oxford Library of Psychology (Oxford ; New York: Oxford University Press, 2012).

${ }^{53}$ Dori Baker and Patrick B. Reyes, 'Religious Educators Are the Future', Religious Education 115, no. 1 (1 January 2020): 1-9, https://doi.org/10.1080/00344087.2020.1706422.

${ }^{54}$ Dawud, 'Towards Establishing Islamic Schools and the Challenges before Muslim Proprietors and Proprietress'.

${ }^{55}$ Roshdi Rashed, Classical Mathematics from Al-Khwarizmi to Descartes (Routledge, 2014).

56 Salem Abdulrahman, Al-Khwarizmi-the Creative Mathematician Who Changed the World (Fakultet strojarstva i brodogradnje (Faculty of Mechanical Engineering And ..., 2016); Nimer Baya'a and Wajeeh Daher, 'From Social Communication to Mathematical Discourse in Social Networking: The Case of Facebook', International Journal of Cyber Ethics in Education (IJCEE) 2, no. 1 (2012): 58-67. 
It was in the 10th Century when systematic geographers began to appear among the Arabs, popular among them were Al-Istakhari whose book was titled Masalik-ul-Mamalik in 950 C.E; Ibn Khanya, best described as a tourist and geographer and Al-Maqdisi who between 983-986 C.E. toured all the Muslim countries known to him and finally came up with a delightful book entitled Absan al-taqasim fil marifeti taqalim (The Best of Classification for the Knowledge of Regions), as a product of his 20 years journeys.

\section{History}

Record shows that it was Abu al-Hassan Ali Mas'udi who began the method of writing history according to topics. Before him, historians used to write history according to events just like they were telling stories, but Al-Mas'udi did not toe this line. Instead of grouping event around years, Al-Mas'udi grouped his own events according to dynasty, king and chief. Other historians such as Ibn Khaldun and Ibn Battutah subsequently followed this pattern. Abu al-Hassan belonged to the Mutazilites and so he embarked on long journeys usually undertook by researchers seeking knowledge.

Ibn Khaldun, full name Abu Zayd Abd-Ar-Rabman Ibn Kbaldun (1332-1406), the greatest of the medieval Islamic historians who was born in Tunis (now in Tunisia) on May 27, 1332. Ibn Khaldun hailed from a Spanish-Arab family and held court positions in what are today Tunisia, Algeria, Morocco, and in Granada, Spain; and was twice imprisoned. However in 1375, he went into seclusion near modern Frenda, Algeria, taking four years to compose his monumental Muqaddamah, the introductory volume to his Kitab al-Ibar (Universal History). In 1382, on his pilgrimage to Mecca; he was offered a chair at the famous Islamic University - Al Azhar by the Sultan of Cairo, who also appointed him judge (qadi) of the Maliki rite of Islam.

The Kitab al-Ibar is a valuable guide to the history of Muslim North Africa and the Berbers. Its six history volumes, however, are overshadowed by the immense significance of the Muqaddamah. In it, Ibn Khaldun outlined a philosophy of history and theory of society that are unprecedented in ancient and medieval writing and that are closely reflected in modern sociology. Societies, he believed, are held together by the power of social cohesiveness, which can be augmented by the unifying force of religion.

Ibn Battütah (1304-1369), Arab traveler and author, whose book Riblah (Travels) is an important source for the history and geography of the medieval Muslim world (Encarta, 2008). Battūtah was a Berber born in Tangiers. His full name was Mubammad ibn Abdullab ibn Battütah. Beginning with his first journey in 1325, a religious pilgrimage to Mecca, he covered some $120,700 \mathrm{~km}$ (some 75,000 mi), extending from Spain in the West to China in the East; from Timbouctou in West Africa to the steppes of Russia. His book includes descriptions of the Byzantine court of Constantinople (present-day İstanbul) and the Black Death of Baghdād, 1348.

Furthermore, the practice of scientific farming was reported by Wells ${ }^{57}$ to be initiated by Muslim Arabs, where good irrigation was devised. Significantly in arts and architecture, the Muslim world showed its artistic versatility in its construction of mosques, palaces, tombs, fences, cities, halls-which Fafunwa ${ }^{58}$ said, it gave the world what is commonly known as 'arabesques'. He further maintains that Taj Mahal in India, which today is acclaimed as one of the Seven Wonders of the World, is a combination of tomb and mosque. No doubt, Muslim cities

\footnotetext{
${ }^{57}$ Wells and Horrabin, The Outline of History, 626.

${ }^{58}$ Fafunwa, History of Education in Nigeria, 44.
} 
of Rabat, Cairo, Tunis, Mecca, Medina, Birni-Kudus, Kano, Ilorin, Bangladesh, Iran, Iraq, Abu Dhabi and very many others are citadels of Muslim's arts and architectures.

Another unique effort of the early Muslim scholars was their versatility in different areas of knowledge, in fact all the Muslim pioneers of modern knowledge were also philosophers and thinkers who are on record till date for their philosophizing skills and modification thoughts of the philosophers for the betterment of the societies.

In summary, Islam and knowledge have been so synonymous from the inception of the religion of Islam. An objective analysis of the religion of Islam, contributions of the Muslim scholars and the modern education would mean that modern education was sourced from the efforts of the Muslim scholars. Kosemani \& Okorosaye-Orubite attest to this assertion when they remarked that ${ }^{59}$ :

traditional Islamic orientation for knowledge informed the attitude of Saracens as the Eastern

Muslims were called - who did not only preserve ancient learning but impressed upon it both in content and in spirit and to them must go the credit for leading Europe out of medievalism.

In Nigeria, there are historical epochs that gave rise to the emergence of Islam and Christianity. This historical epochs or events have created all the basic human groupingscountries, classes, religions and all the loyalties that attach to these.

\section{CONCLUSION}

If the preoccupation of early Muslims was directed at scholasticism, where those foremost Islamic torchbearers were known to be exploring different areas of knowledge, they were recognized for series of breakthroughs and discoveries in virtually all facets of human endeavours; the current manifestations many centuries after their efforts have left the Muslim world with many questions than answers. What therefore has happened that crises of all kinds have replaced the erudition and scholasticism of the Muslim world? From the study, efforts of the early Muslims were quite commendable, pioneering the different modern disciplines in medicine, arts, sciences, engineering, and technology. Why are the once celebrated frontliners now operating from the rear, overtaken by those who were initially looking up to the Muslim world for solution to critical areas of their existence? Why are the Muslims of today seeing wars, hostilities and violence as their preoccupation? The tentative answer may be as a result of greed or misplacement of priorities. Muslim leaders are so much political, selfish and enmeshed in corrupt practices, to the extent that governance is no longer centred on the people and the society. They are blindfolded with politics and external influences that consistently engineered crisis among the Muslim nations that are expected to collaborate and be advancing the frontiers of knowledge which ultimately make them formidable, respected and indispensable.

The legacies that the early Muslim scholars bequeathed the world seem to have been allowed stolen from the Muslims. The golden legacies have now been freely or unconsciously surrendered to the West, because the livelihood of the world today is hinged on the dictate and directives of the West that once looked up to the Muslim world for survival, as chronicled in this paper.

\footnotetext{
${ }^{59}$ Kosemani and Okorosaye-Orubite, History of Nigerian Education: A Contemporary Analysis, 12.
} 


\section{RECOMMENDATIONS}

It is never late to reclaim the acclaimed stolen legacies, if Muslim leaders of today see themselves as agents of change and redirect their energies towards achieving peace and unity of ummah in the entire world; there and then, the cracked wall among the Muslim nations can be mended. Muslim students have been excelling and making their families proud; by extension, their religious identity. In our colleges and universities, Muslim children are graduating atop their classes. Many first class Muslim students have emerged in engineering, law, medicine, technology, economics, telecommunication, in humanities and other social science disciplines. If Muslim leaders or government focus their attention on scholasticism, every other thing will certainly fall in place. Identifying talents and nursing them with commitment and focus. Scholarship and other motivating awards should be internally, regionally and internationally established for Muslim students to forge ahead. It is also important that Muslim societies should imbibe this secular education, since it has come to stay. It should also be known that secular education can even be used as a vehicle or medium to propagate the religion. Education is important; we all need knowledge to survive.

\section{REFERENCES}

Abbas, Femi. 'Encounter with Richard Akinjide on Islam - The Nation Nigeria News'. The Nation. Latest Nigeria News, Nigerian Newspapers, Politics (blog), 9 October 2020. https://thenationonlineng.net/encounter-with-richard-akinjide-on-islam/.

Abdullatif, Mohammad. 'Al-Battani Contributions in Astronomy and Mathematics'. Malaysia: IIUM Press, 2011.

Abdulrahman, Salem. Al-Khwarizmi-the Creative Mathematician Who Changed the World. Fakultet strojarstva i brodogradnje (Faculty of Mechanical Engineering And ..., 2016.

Abdulrahman, Y. M. Nigerian Educational History and Policy: The Beginning of the Past and Past of the Future. Revision. Nigeria: Port Harcourt: M \& J Grand Orbit Communications Ltd. ISBN, 2017.

Adamson, Peter, and Peter Adamson. Philosophy in the Islamic World. A History of Philosophy without Any Gaps, volume 3. United Kingdom: Oxford University Press, 2018.

Adeyemi, Kamil Adeleke. 'The Trend of Arabic and Islamic Education in Nigeria: Progress and Prospects'. Open Journal of Modern Linguistics 06, no. 03 (2016): 197-201. https://doi.org/10.4236/ojml.2016.63020.

Amini, Babak. 'Agamenon R. E. Oliveira, \&lt;I\&gt;A History of the Work Concept: From Physics to Economics\&lt;/I\&gt; (New York and London: Springer, 2014)'. Advances in Historical Studies 04, no. 04 (2015): 336-37. https://doi.org/10.4236/ahs.2015.44023.

Baba, Nasir Mohammed. 'Islamic Schools, the Ulama, and the State in the Educational Development of Northern Nigeria'. Bulletin de l'APAD, no. 33 (1 August 2011). https://doi.org/10.4000/apad.4092.

Baker, David B., ed. The Oxford Handbook of the History of Psychology: Global Perspectives. Oxford Library of Psychology. Oxford ; New York: Oxford University Press, 2012.

Baker, Dori, and Patrick B. Reyes. 'Religious Educators Are the Future'. Religious Education 115, no. 1 (1 January 2020): 1-9. https://doi.org/10.1080/00344087.2020.1706422. 
Baya'a, Nimer, and Wajeeh Daher. 'From Social Communication to Mathematical Discourse in Social Networking: The Case of Facebook'. International Journal of Cyber Ethics in Education (IJCEE) 2, no. 1 (2012): 58-67.

Brenet, Jean-Baptiste. 'Relation as Key to God's Knowledge of Particulars in the Tahăfut AlTahāfut and the Damīma: A Cross-Talk Between Averroes, Al-Ġaz̄̄l̄ and Avicenna'. Arabic Sciences and Philosophy 30, no. 1 (March 2020): 1-26. https://doi.org/10.1017/S0957423919000109.

Dauda, Aliyu. State Education in Northern Nigeria. 1st ed. Kano: Gidan Dabino, 2002.

Dawud, M. 'Towards Establishing Islamic Schools and the Challenges before Muslim Proprietors and Proprietress'. Presented at the the National Conference of Nigerian Association of Model Islamic Schools (NAMIS) in Ibadan., Nigeria, 2003.

Dunmade, Israel. 'Lifecycle Assessment Education in Nigeria: An Exploratory Evaluation of the Trend'. Procedia Manufacturing 35 (1 January 2019): 447-52. https://doi.org/10.1016/j.promfg.2019.05.065.

Esposito, John L. The Oxford History of Islam. Oxford University Press, 2000.

Fafunwa, A. Babs. History of Education in Nigeria. London: Allen and Unwin, 1974.

Florence, Ronald, Steven N. Shore, Steven N. Shore, Christian Nitschelm, Thomas R. Williams, Raghini S. Suresh, Stephen Gaukroger, et al. 'Būzjānī: Abū Al-Wafā' Muḥammad Ibn Muḥammad Ibn Yaḥyā Al-Būzjānì'. In The Biographical Encyclopedia of Astronomers, edited by Thomas Hockey, Virginia Trimble, Thomas R. Williams, Katherine Bracher, Richard A. Jarrell, Jordan D. Marché, F. Jamil Ragep, JoAnn Palmeri, and Marvin Bolt, 188-89. New York, NY: Springer New York, 2007. https://doi.org/10.1007/978-0-387-30400-7_223.

Galandaci, B. S. 'Islamisation of Knowledge Undertaking and the Contemporary Nigerian Educational System.' National Conference of Nigerian Association of Model Islamic Schools (NAMIS), 2003.

Garcia, Danilo, Trevor Archer, and Ann-Christine Andersson Arntén. Character, Responsibility, and Well-Being: Influences on Mental Health and Constructive Behavior Patterns, 2016.

Glatzer, N. N. Averroes. Encarta, 2008.

Heinrichs, W. P, Clifford Edmund Bosworth, E. J. van Donzel, G Lecomte, P. J Bearman, H. A. R Gibb, Gudrun Krämer, Denis Martinge, John Abdallah Nawas, and Everett K Rowson. The Encyclopaedia of Islam, 1960.

Hockey, Thomas A., Virginia Trimble, and Katherine Bracher, eds. The Biographical Encyclopedia of Astronomers. Springer Reference. New York: Springer, 2007.

Humphreys, Sara, Máiréad Dunne, Naureen Durrani, Swadchet Sankey, and Jiddere Kaibo. 'Becoming a Teacher: Experiences of Female Trainees in Initial Teacher Education in Nigeria'. Teaching and Teacher Education 87 (1 January 2020): 102957. https://doi.org/10.1016/j.tate.2019.102957.

Jimoh, S. A. Islamic Education in Nigeria: An Overview. In S. A. Jimoh (Ed.) Foundations of Education. Ilorin: Niger: Indemac (Nigeria Publishers) Ltd., 2004.

Kennedy-Day, Kiki. Books of definition in Islamic philosophy: the limits of words. London; New York: RoutledgeCurzon, 2003. 
King, David A. 'E. S. Kennedy: Survey of Islamic Astronomical Tables 1956'. Accessed 5 November https://www.academia.edu/38529832/E_S_Kennedy_Survey_of_Islamic_Astronomi cal_Tables_1956.

Kosemani, J. M, and A. K Okorosaye-Orubite. History of Nigerian Education: A Contemporary Analysis. Nigeria: Port Harcourt: University of Port Harcourt Press, 2002.

Lari, Mujtaba Musavi, and Mujtabá Mūsavī Lārī. Western Civilisation Through Muslim Eyes. F. J. Goulding, 1977.

Maigida, Abdulrahman Yusuf. 'The Contributions of Islamic Organisations to Modern Education Development in Nigeria 1922-2008'. Thesis in the Department of Educational Foundations, University of Port Harcourt., 2010.

Stories. 'Microsoft Releases Microsoft Student with Encarta Premium 2008', 26 June 2007. https://news.microsoft.com/2007/06/26/microsoft-releases-microsoft-student-withencarta-premium-2008/.

Modanlou, Houchang D. 'A Tribute to Zakariya Razi (865-925 AD), an Iranian Pioneer Scholar', 2008.

Moussa, Ali. 'Mathematical Methods in Abū Al-Wafā's Almagest and the Qibla Determinations'. Arabic Sciences and Philosophy 21, no. 1 (March 2011): 1-56. https://doi.org/10.1017/S095742391000007X.

Mujtaba, Sayid, and Rukni Musawi Lari. Western Civilisation Through Muslim Eyes. Sadr Publishing House, 1977.

Niyozov, Sarfaroz, and Nadeem Memon. 'Islamic Education and Islamization: Evolution of Themes, Continuities and New Directions'. Journal of Muslim Minority Affairs 31, no. 1 (1 March 2011): 5-30. https://doi.org/10.1080/13602004.2011.556886.

O'Connor, J J, and E F Robertson. 'Al-Battani - Biography'. Maths History, 1999. https://mathshistory.st-andrews.ac.uk/Biographies/Al-Battani/.

Rashed, Roshdi. Classical Mathematics from Al-Khwarizmi to Descartes. Routledge, 2014.

Renard, John. 101 Questions and Answers on Islam. New York: Paulist Press, 2005.

Rosenthal, Franz. 'Ar-Razi on the Hidden Illness'. Bulletin of the History of Medicine 52, no. 1 (1978): 45-60.

Rusyd, Ibnu. Bidayatul Mujtahid Wa Nihayah Al-Muqtashid. Lebanon: Beirut: Dar al Kutub al 'Ilmiyah, 1990.

Selin, Helaine, ed. Mathematics Across Cultures: The History of Non-Western Mathematics. Science Across Cultures: The History of Non-Western Science. Springer Netherlands, 2000. https://doi.org/10.1007/978-94-011-4301-1.

Shihadeh, Ayman. The Teleological Ethics of Fakhr Al-Din al-Razi. Vol. 64. Рипол Классик, 2006.

TMO. 'Muslim Scientists and Thinkers-Abul Wafa Ibn Ismail al Buzjani'. The Muslim Observer (blog), 26 November 2008. http://muslimobserver.com/muslim-scientists-andthinkers-abul-wafa-ibn-ismail-al-buzjani/.

Wells, H. G. (Herbert George), and J. F. (James Francis) Horrabin. The Outline of History: Being a Plain History of Life and Mankind. Edited by Ernest Barker, Harry Johnston, E. Ray (Edwin Ray) Lankester, and Gilbert Murray, 2014. http://www.gutenberg.org/ebooks/45368. 
Muslim in Pioneering Modern Knowlegde,...

Yakubu, Abubakar. A Comparative Overview of the Pondok and the Traditional Madrasah in Nigeria, 2018.

Yusuf Maigida, Abdulrahman. 'Contemporary Islamic Education in Nigeria from the Rear View Mirror'. American Journal of Educational Research 6, no. 4 (31 March 2018): 329-43. https://doi.org/10.12691/education-6-4-6. 